\title{
A Case of Pulmonary Hemorrhage and Renal Failure
}

\author{
Alexa S. Meara, ${ }^{*}$, Daphne M. Harrington ${ }^{1}$, Jennifer Foster ${ }^{2}$, Tushar J. Vachharajani ${ }^{3}$ and Tejas Desai ${ }^{4}$ \\ ${ }^{I}$ Division of General Internal Medicine, Department of Internal Medicine, The Brody School of Medicine at East \\ Carolina University, USA \\ ${ }^{2}$ Cleveland Clinic Florida - Weston, 2950 Cleveland Clinic Blvd., Weston, FL 33331, USA \\ ${ }^{3}$ Nephrology Section, W. G. (Bill) Hefner VA Medical Center, Salisbury, NC, USA \\ ${ }^{4}$ Division of Nephrology and Hypertension, Department of Internal Medicine, The Brody School of Medicine at East \\ Carolina University, USA
}

\begin{abstract}
Background: Alveolar hemorrhage can be seen in many vasculitic disorders. However, granulomatosis polyangiitis (formerly Wegener's granulomatosis) uncommonly presents with life threatening alveolar hemorrhage and has only been discussed in a few case reports [1].

Case Presentation: A 53 year old Caucasian male presented with hemoptysis and profound anemia. Two weeks prior, he had presented with abdominal pain with normal renal function and numerous pulmonary nodules. During the current admission, the patient was hypoxic with acute renal failure requiring hemodialysis. Urine sediment demonstrated dysmorphic red blood cells. A bronchoscopy revealed diffuse alveolar hemorrhage. The diagnosis of pulmonary-renal syndrome was made and therapeutic plasma exchange was initiated. Laboratory studies were significant for a c-ANCA titer positive at 1:640 FIU and anti-proteinase (PR)-3 antibody titer positive with $78.3 \mathrm{U} / \mathrm{ml}$. Renal biopsy demonstrated necrotizing crescentic glomerulonephritis. A diagnosis of granulomatosis vasculitis was determined.

Conclusion: Alveolar hemorrhage is rare to be the presenting symptom of granulomatosis vasculitis where the common presenting features are recurrent sinusitis, epistaxis, chronic otitis media or rhinitis. Physicians should consider granulomatosis vasculitis in the differential diagnosis of pulmonary-renal syndrome presenting with hemoptysis.
\end{abstract}

Keywords: Granulomatosis, vasculitis, pulmonary hemorrhage, renal insufficiency, Wegener's, dialysis, plamapharesis.

\section{INTRODUCTION}

Granulomatosis polyangiitis is one of three pulmonaryrenal syndromes which are associated with antineutrophil cytoplasmic antibodies, either c-ANCA or p-ANCA, due to autoantibodies against target antigens proteinase-3 and myeloperoxidase (MPO), respectively. Classically, when a patient presents with pulmonary hemorrhage and necrotizing glomerulonephritis anti-glomerular basement membrane disease (anti-GBM disease) is thought of first. Granulomatosis polyangiitis is increasing in incidence and thus becoming aware and comfortable with the different clinical presentations of this disease process can be life saving. We describe a case of granulomatosis polyangiitis presenting with diffuse alveolar hemorrhage (DAH).

\section{CASE PRESENTATION}

This case is a 53 year old Caucasian male with a history of tobacco abuse was over the past few months been treated twice with azithromycin and prednisone for what was believed to be bronchitis. Six weeks later he presented to the Emergency Department (ED) with abdominal pain. The

*Address correspondence to this author at Department of Internal Medicine, Brody School of Medicine at ECU, 600 Moye Blvd, VMC MA-350, Greenville, NC 27834, USA; Tel: 52-744-4555; E-mail: simona@ecu.edu workup was significant for normal laboratory studies (Table 1) and numerous pulmonary nodules, found on a chest $x$-ray and confirmed with a computed tomography scan (CT) of the chest. Subsequently, an outpatient positron-emission test (PET) scan showed metabolically active pulmonary nodules and a biopsy was scheduled. One week later and prior to the biopsy, he presented to the ED with hemoptysis. He was coughing black to bright red blood clots with whitish sputum for three days and, on the day of presentation, frank blood clots. He confirmed mild shortness of breath at rest and generalized weakness along with nausea and vomiting. He denied hematemesis. The patient worked as a maintenance worker and welder and had no history of exposure to

Table 1. Laboratory Findings from Two Weeks Prior to Current Admission

\begin{tabular}{|c|c|c|}
\hline \multirow{2}{*}{ Laboratory } & \multicolumn{1}{c}{ Value } & Normal Value \\
\hline Hemoglobin & $12 \mathrm{~g} / \mathrm{dL}$ & $13-18 \mathrm{~g} / \mathrm{dL}$ \\
\hline Hematocrit & $32 \%$ & $40-52 \%$ \\
\hline Potassium & $3.9 \mathrm{mEq} / \mathrm{L}$ & $3.5-5 \mathrm{mEq} / \mathrm{L}$ \\
\hline BUN & $22 \mathrm{mg} / \mathrm{dL}$ & $6-20 \mathrm{mg} / \mathrm{dL}$ \\
\hline Creatinine & $1.1 \mathrm{mg} / \mathrm{dL}$ & $0.6-1.2 \mathrm{mg} / \mathrm{dL}$ \\
\hline
\end{tabular}


asbestos. Moreover, he had no recent travel outside the United States or sick contacts and NSAIDs on occasion $\mathrm{He}$ denied fever, chills, weight loss, loss of appetite, chest pain, abdominal pain, diarrhea, constipation, hematuria, changes in urine output, headaches, and rashes.

On examination, the patient was pale, afebrile with a blood pressure of $147 / 82 \mathrm{mmHg}$ and tachycardic at 120 beats per minute. He was hypoxic (pulse oximtery reading of $83 \%$ on room air) and tachypneic (respiratory rate of 30 breaths per minute). The examination was also significant for coarse breath sounds bilaterally in all lung fields and generalized poor air movement.

Initial laboratory studies were significant for profound anemia and acute renal failure (Table 2). Urine sediment

Table 2. Laboratory Findings from this Admission

\begin{tabular}{|c|c|c|}
\hline Laboratory & Value & Normal Value \\
\hline White Blood Cell & $15 \mathrm{k} / \mathrm{uL}$ & $4.5-11 \mathrm{k} / \mathrm{uL}$ \\
\hline Hemoglobin & $5.7 \mathrm{~g} / \mathrm{dL}$ & $13-18 \mathrm{~g} / \mathrm{dL}$ \\
\hline Hematocrit & $16.1 \%$ & $40-52 \%$ \\
\hline Platelets & $185 \mathrm{k} / \mathrm{uL}$ & $150-440 \mathrm{k} / \mathrm{uL}$ \\
\hline Sodium & $132 \mathrm{mEq} / \mathrm{L}$ & $135-145 \mathrm{mEq} / \mathrm{L}$ \\
\hline Potassium & $7.1 \mathrm{mEq} / \mathrm{L}$ & $3.5-5 \mathrm{mEq} / \mathrm{L}$ \\
\hline Chloride & $102 \mathrm{mEq} / \mathrm{L}$ & $99-19 \mathrm{mEq} / \mathrm{L}$ \\
\hline Bicarbonate & $18 \mathrm{mEq} / \mathrm{L}$ & $22-33 \mathrm{mEq} / \mathrm{L}$ \\
\hline BUN & $208 \mathrm{mg} / \mathrm{dL}$ & $6-20 \mathrm{mg} / \mathrm{dL}$ \\
\hline Creatinine & $12.11 \mathrm{mg} / \mathrm{dL}$ & $0.6-1.2 \mathrm{mg} / \mathrm{dL}$ \\
\hline Glucose & $121 \mathrm{mg} / \mathrm{dL}$ & $70-105 \mathrm{mg} / \mathrm{dL}$ \\
\hline Calcium & $8.7 \mathrm{mg} / \mathrm{dL}$ & $8.5-10.5 \mathrm{mg} / \mathrm{dL}$ \\
\hline Phosphorus & $10.3 \mathrm{mg} / \mathrm{dL}$ & $2.9-4.8 \mathrm{mg} / \mathrm{dL}$ \\
\hline Magnesium & $2.1 \mathrm{mg} / \mathrm{dL}$ & $1.6-2.6 \mathrm{mg} / \mathrm{dL}$ \\
\hline AST & $9 \mathrm{U} / \mathrm{L}$ & $10-37 \mathrm{U} / \mathrm{L}$ \\
\hline ALT & $12 \mathrm{U} / \mathrm{L}$ & $10-49 \mathrm{U} / \mathrm{L}$ \\
\hline Alkaline Phosphatase & $63 \mathrm{U} / \mathrm{L}$ & $41-120 \mathrm{U} / \mathrm{L}$ \\
\hline Total bilirubin & $0.4 \mathrm{mg} / \mathrm{dL}$ & $0.3-1.2 \mathrm{mg} / \mathrm{dL}$ \\
\hline Total protein & $6 \mathrm{~g} / \mathrm{dL}$ & $6.2-8.3 \mathrm{~g} / \mathrm{dL}$ \\
\hline Albumin & $2.8 \mathrm{~g} / \mathrm{dL}$ & $3.4-4.9 \mathrm{~g} / \mathrm{dL}$ \\
\hline Lactate dehydrogenase & $256 \mathrm{U} / \mathrm{L}$ & $118-273 \mathrm{U} / \mathrm{L}$ \\
\hline Ferritin & $782 \mathrm{ng} / \mathrm{mL}$ & $22-322 \mathrm{ng} / \mathrm{mL}$ \\
\hline Transferrin & $144 \mathrm{mg} / \mathrm{dL}$ & $203-362 \mathrm{mg} / \mathrm{dL}$ \\
\hline Haptoglobin & $146 \mathrm{mg} / \mathrm{dL}$ & $40-240 \mathrm{mg} / \mathrm{dL}$ \\
\hline Iron & $22 \mathrm{ug} / \mathrm{dL}$ & $35-194 \mathrm{ug} / \mathrm{dL}$ \\
\hline Iron Binding Capacity & $209 \mathrm{ug} / \mathrm{dL}$ & $250-450 \mathrm{ug} / \mathrm{dL}$ \\
\hline Transferrin Saturation & $11 \%$ & $20-50 \%$ \\
\hline Complement C3 & $128 \mathrm{mg} / \mathrm{dL}$ & $90-170 \mathrm{mg} / \mathrm{dL}$ \\
\hline Complement C4 & $27 \mathrm{mg} / \mathrm{dL}$ & $12-36 \mathrm{mg} / \mathrm{dL}$ \\
\hline INR & 1.0 & \\
\hline PT & 10.6 seconds & 9.7-11.3 seconds \\
\hline aPTT & 27.5 seconds & 23-31 seconds \\
\hline Urine analysis & $\begin{array}{c}\text { Cloudy, Straw, specific gravity } 1.010, \mathrm{pH} 5,2+\text { proteins, } \\
\text { negative glucose, negative ketones, negative bilirubin, } \\
\text { too numerous to count RBCs, } 3+\text { hemoglobin, no WBC, } \\
\text { negative leukocyte esterase, negative nitrites, normal } \\
\text { urobilinogen, amorphous sediment }\end{array}$ & $\begin{array}{c}\text { Clear, Yellow, specific gravity } 1.005-1.030, \mathrm{pH} 4.5-8 \text {, } \\
\text { negative proteins, negative glucose, negative ketones, } \\
\text { negative bilirubin, 0/HPF RBCs, negative hemoglobin, } \\
\text { 0/HPF WBC, negative leukocyte esterase, negative } \\
\text { nitrites, normal urobilinogen }\end{array}$ \\
\hline
\end{tabular}


demonstrated a moderate amount of dysmorphic red blood cells (RBC) with no RBC casts but a moderate amount of muddy brown casts. The chest x-ray (Fig. 1) showed diffuse bilateral airspace opacities that were non-specific concerning for pulmonary edema, pulmonary hemorrhage, ARDS, or pneumonia. Given the presence of hemoptysis, urinary red cell casts and acute kidney injury, the possibility of a pulmonary-renal syndrome was considered. $\mathrm{He}$ was intubated and placed on mechanical ventilation and bronchial lavage was initially sent from the patient confirming pulmonary hemorrhage seen in Fig. (2). The patient was started on a course of plasmapheresis and supportive hemodialysis. Immunologic studies were done and are reflected in Table 3. Significant findings included c-ANCA titer of 1:640 FIU, and a negative anti-GBM antibody titer. A renal biopsy was performed and was significant for necrotizing crescentic glomerulonephritis with fibrocellular crescents in nine of sixteen glomeruli along with acute tubular injury (Figs. 3, 4) with a lung biopsy (Figs. 5-7) indicating the presence of acute and organizing infarct with numerous vascular thrombi and necrotizing vasculitis.

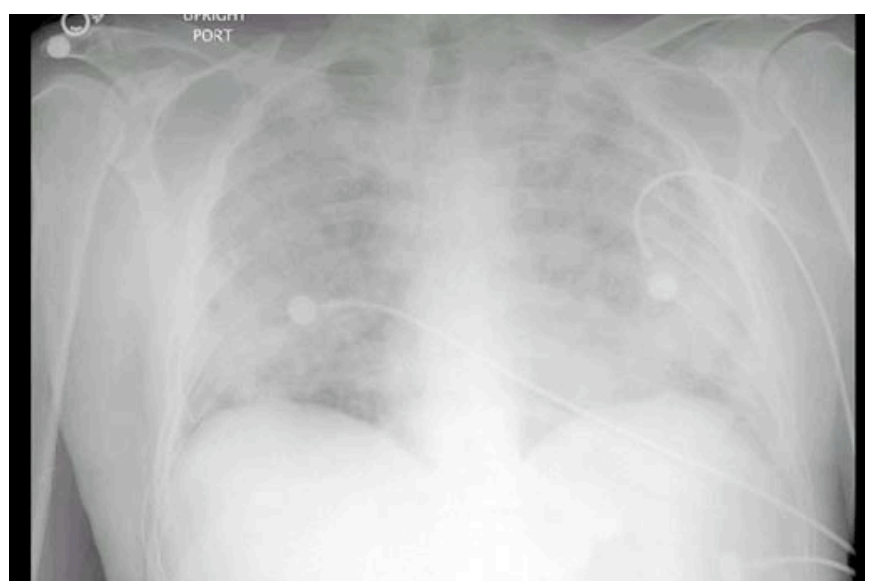

Fig. (1). Portable upright AP view showing diffuse bilateral airspace opacities. Differential diagnosis includes pulmonary edema, pulmonary hemorrhage, ARDS, and pneumonia.
The definitive diagnosis of granulomatosis polyangiitis was made. As the diagnosis was being confirmed renal replacement therapy was begun as well as four treatments of plasmapharesis were completed. Once the diagnosis was confirmed, plasmapharesis was stopped and the patient was started on cyclophosphamide and prednisone along with dialysis support. Immunologically he achieved remission, but failed to recover renal function and remains dependent on hemodialysis (Graph $\mathbf{1}$ ).

\section{DISCUSSION}

Granulomatosis polyangiitis is a pauci-immune vasculitis, and is one of the many causes of pulmonary-renal syndrome. Etiologies of pulmonary-renal syndrome include anti-GBM disease, and microscopic polyangiitis (MPA), and granulomatosis polyangiitis. This patient's clinical presentation of DAH with necrotizing crescentic glomerulonephritis was atypical but immunologically consistent with granulomatosis polyangiitis due to high titers of c-ANCA and PR-3 antibodies.

The incidence of granulomatosis polyangiitis has almost doubled from since 1990 to 1 in 64.8 million in 2005 and mean age range at presentation is 40 to 60 years [2]. Granulomatosis polyangiitis is a systemic vasculitis that affects both medium and small vessels. Typically, granulomatosis polyangiitis involves the upper respiratory tract, lungs, kidneys and joints and is frequently an indolent disease [3]. Most of these patients have c-ANCA positive antibodies and less commonly myeloperioxidase positive antibodies [4]. Approximately $99 \%$ of patients with granulomatosis polyangiitis will develop upper respiratory tract involvement during the disease process [2,4]. Pulmonary involvement ranges from $60-85 \%$, classically as capillaritis or granulomatosis masses, which could lead to diffuse alveolar hemorrhage (DAH) [2]. DAH has been reported over a wide range from $7-40 \%$, and usually the results of a mass or untreated capillaritis $[4,6]$. DAH is characteristically not the presenting symptom, as seen in our

Table 3. Immunologic Studies

\begin{tabular}{|c|c|c|}
\hline Antinuclear antibody & $<7.5 \mathrm{IU} / \mathrm{mL}$ & $<7.5 \mathrm{IU} / \mathrm{mL}$ \\
\hline Glomerular Basement Membrane Antibody & $<1.0 \mathrm{AI}$ & $<1.0 \mathrm{AI}$ \\
\hline Hepatitis B Surface Antigen Antibody & Postitive & \\
\hline Hepatitis C Virus Antibody & Negative & Negative \\
\hline Neutrophil Myeloperoxidase Antibody & $<9.0 \mathrm{U} / \mathrm{mL}$ & $<9.0 \mathrm{U} / \mathrm{mL}$ \\
\hline Anti-Streptolysin (ASO) Antibody & $53 \mathrm{IU} / \mathrm{mL}$ & $\leq 200 \mathrm{IU} / \mathrm{mL}$ \\
\hline
\end{tabular}




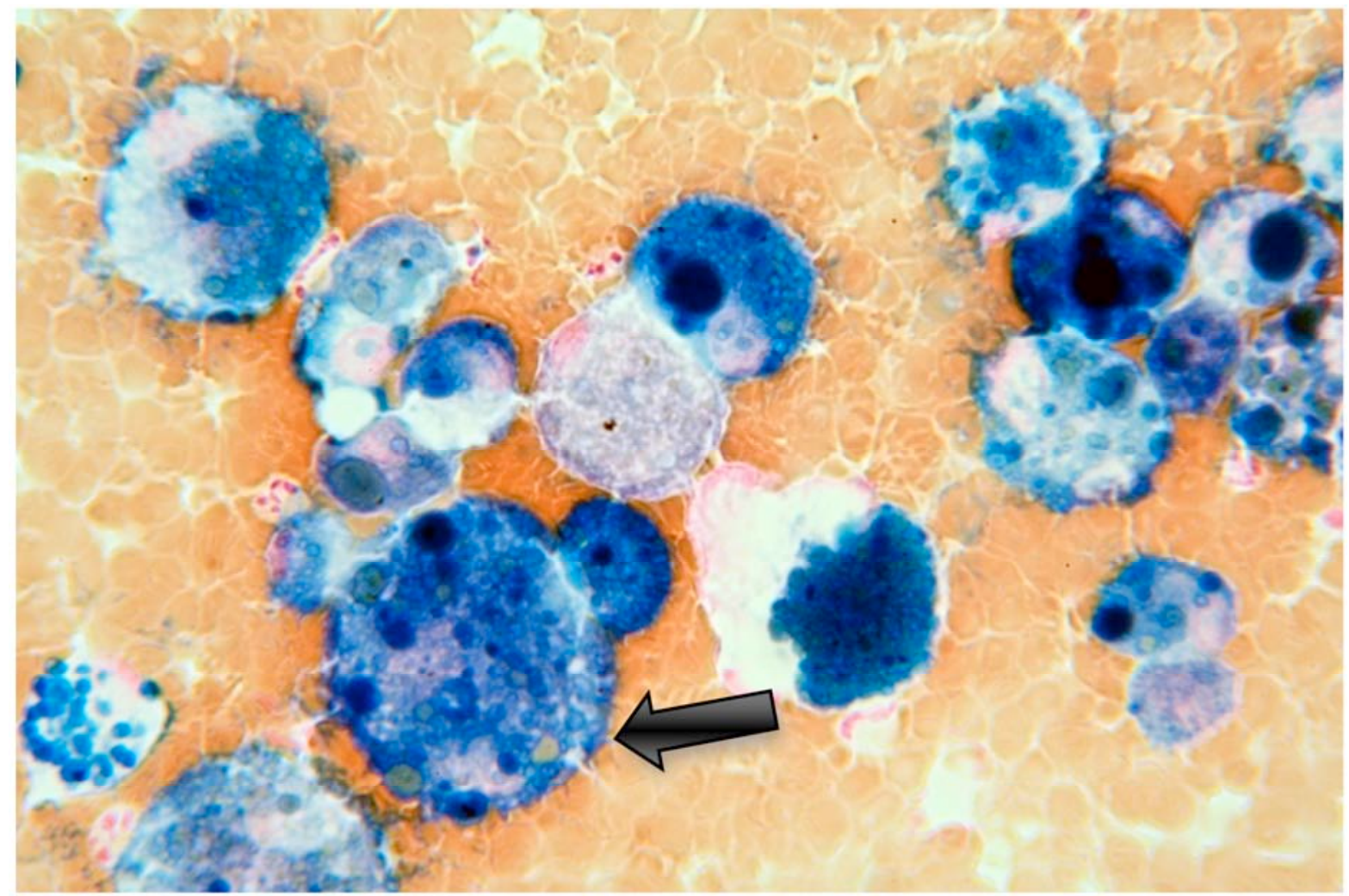

Fig. (2). Bronchial lavage showing hemosiderin laden macrophages with an index of $77 \%$ indicative of pulmonary hemorrhage seen on light microscopy with magnification at $40 \mathrm{x}$ with an iron stain.

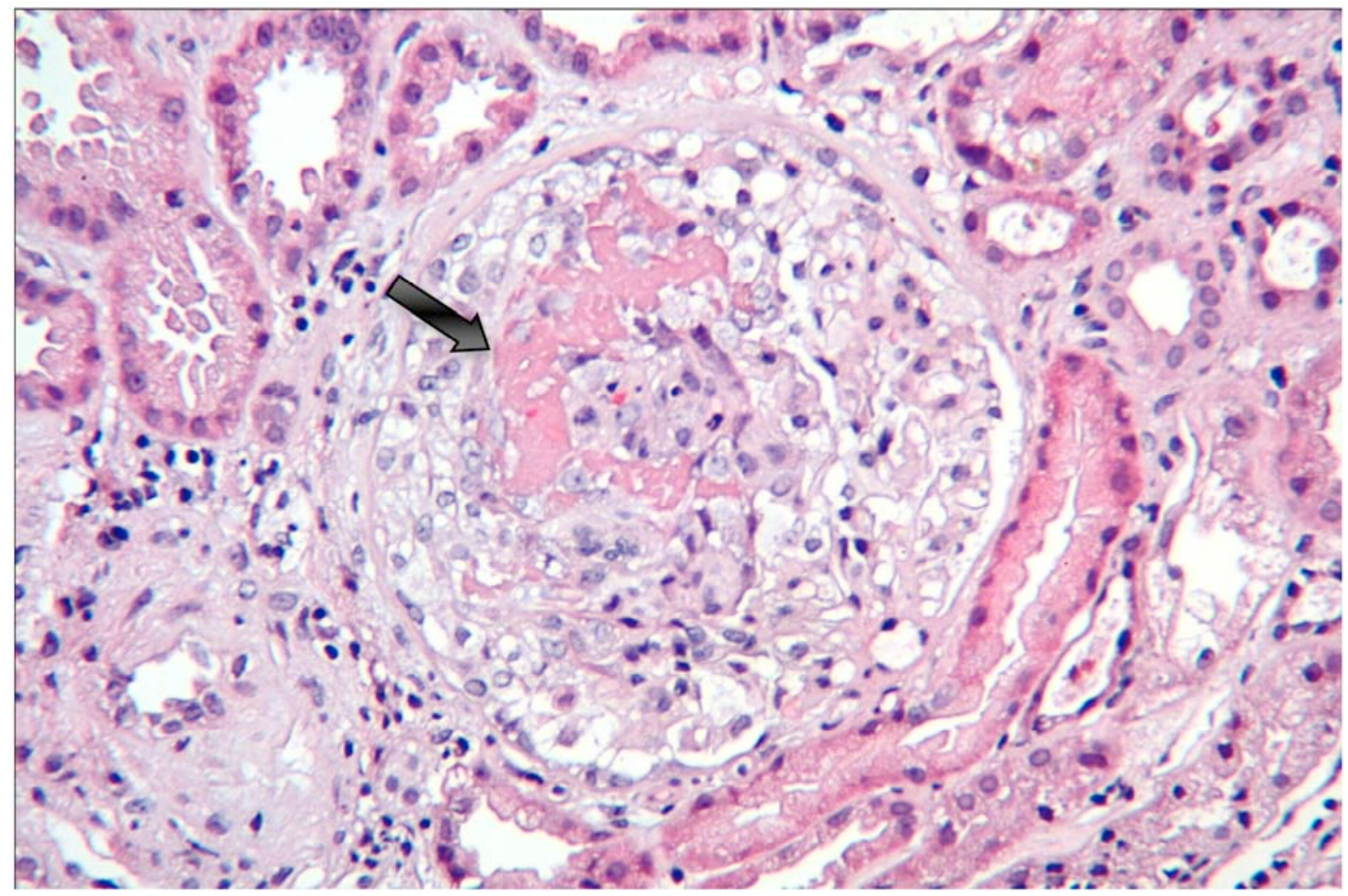

Fig. (3). Kidney biopsy showing necrotizing glomerulonephritis in the glomerulus with crescents seen on light microscopy with magnification at $20 \mathrm{x}$ with a hematoxylin and eosin stain. 


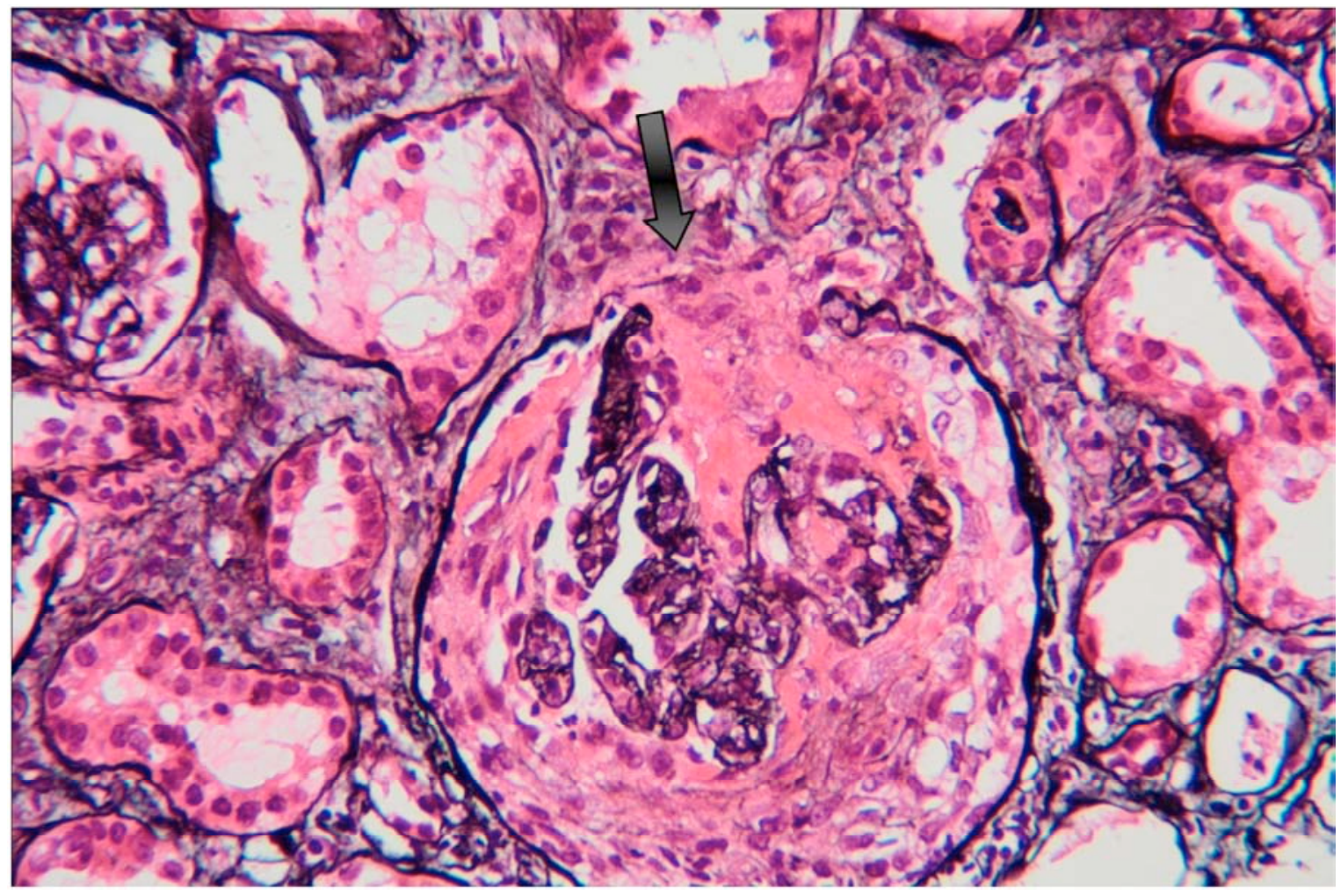

Fig. (4). Kidney biopsy shows glomerular tuft rupture seen on light microscopy with magnification at 20X with a Jones methenamine silver stain.

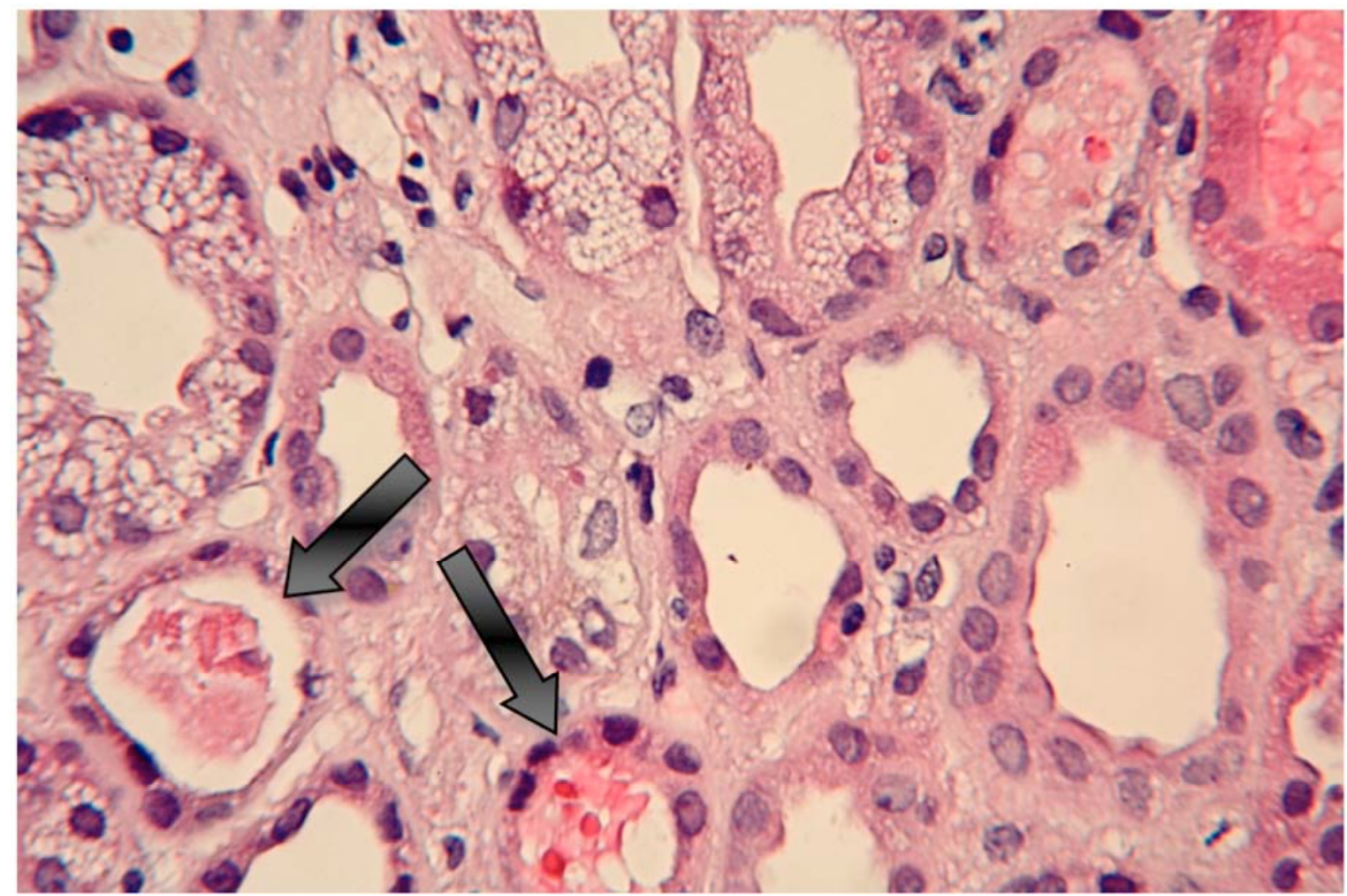

Fig. (5). Lung biopsy shows a necrotizing vasculitis that is associated with hemorrhagic infarct in the lung parenchyma seen with light microscopy with magnification at $10 \mathrm{x}$ with a hematoxylin and eosin stain. 


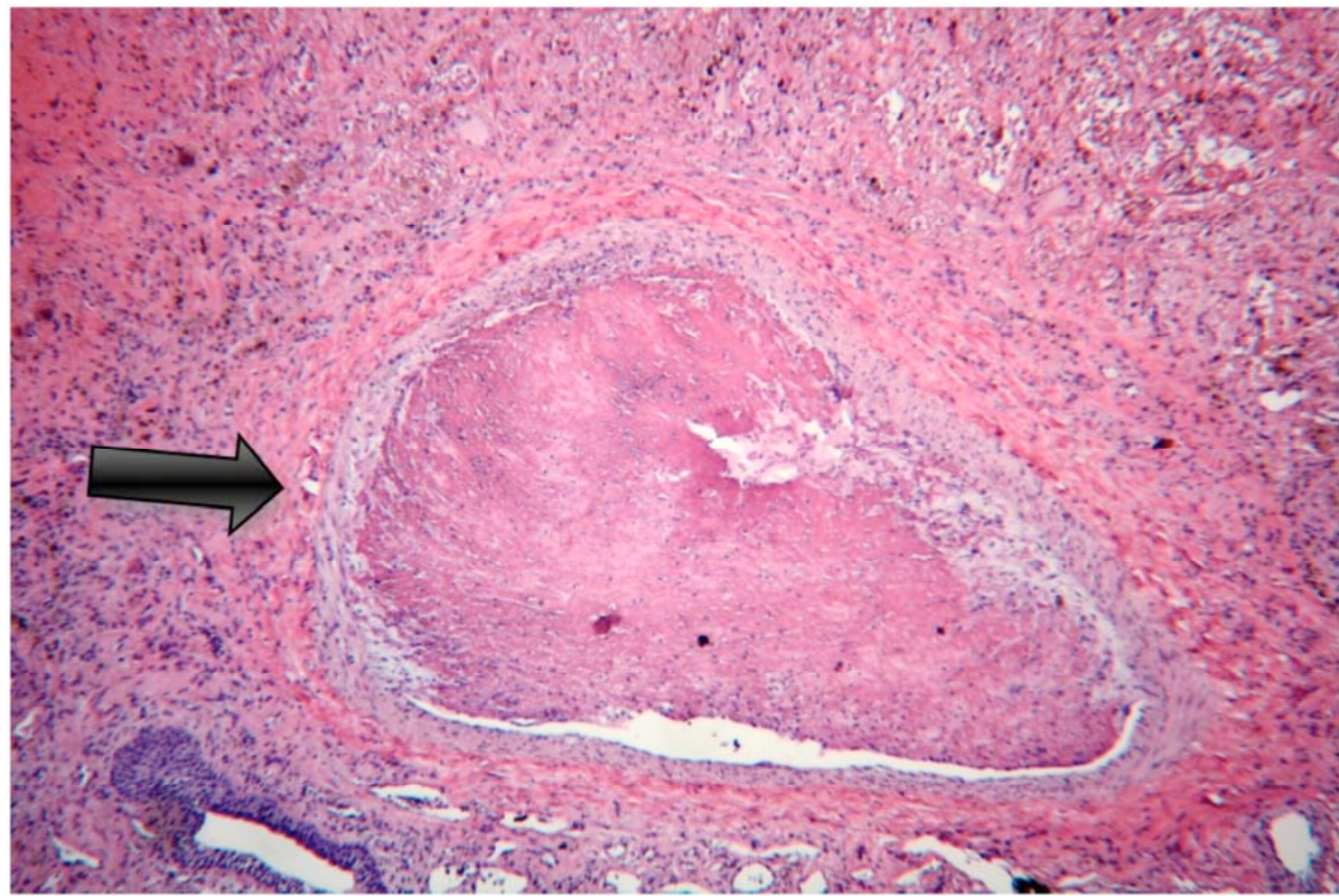

Fig. (6). Lung biopsy shows vascular thrombi in the lung seen with light microscopy with magnification at $4 x$ with a hematoxylin and eosin stain.

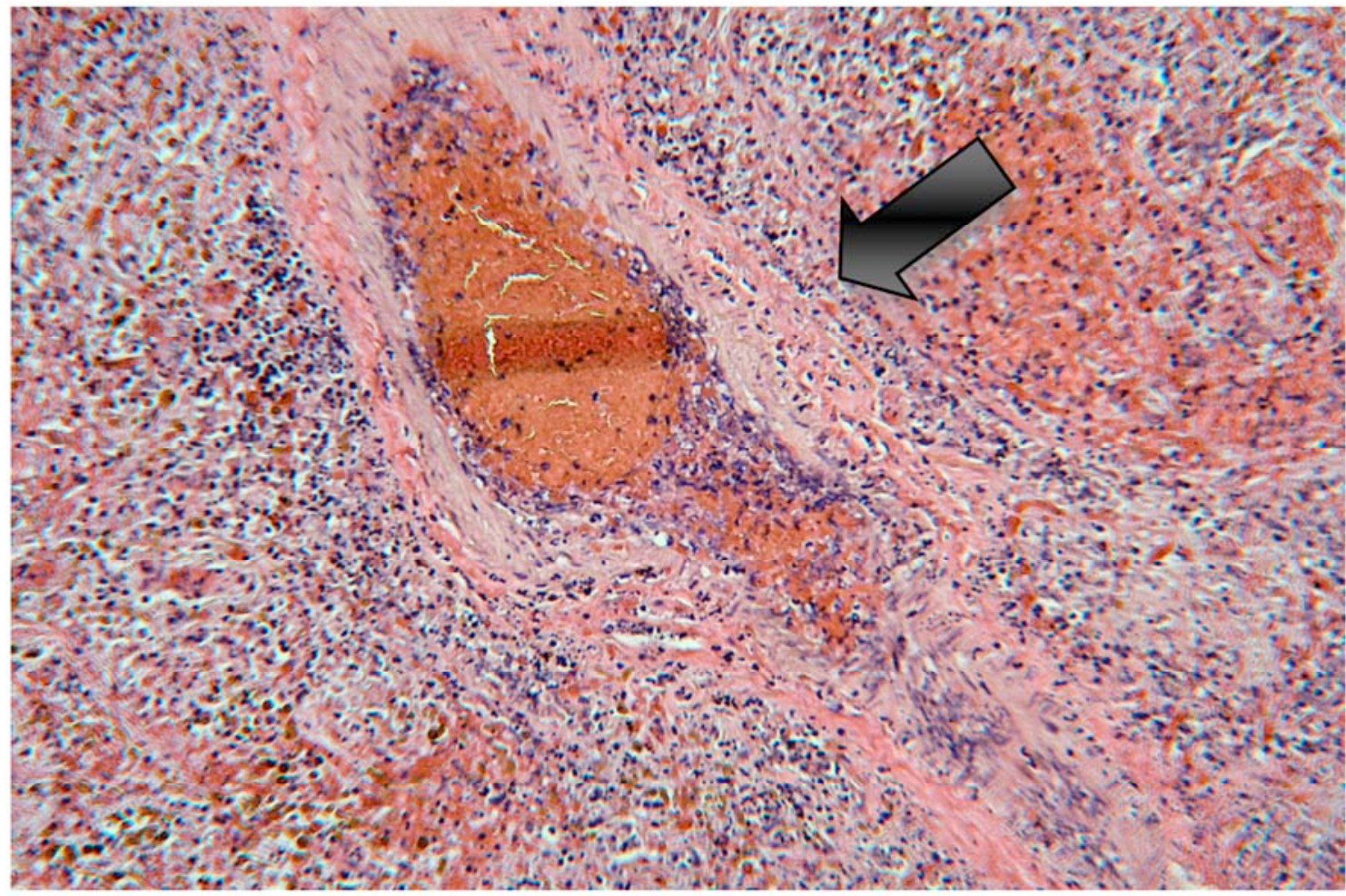

Fig. (7). Lung biopsy shows necrotizing vasculitis that is associated with hemorrhagic infarct seen with light microscopy with magnification at 10x with a hematoxylin and eosin stain.

case. It has been agreed upon that DAH does have an increase mortality rate of $60 \%$, however, if granulomatosis polyangiitis is left untreated the mortality rate is $91 \%[1,5,7-$ 9].
Glomerulonephritis is also been reported in varying frequencies from $40-70 \%$ [2]. Typically only about $25 \%$ require dialysis and only half of those will progress to endstage renal disease $[1,2]$. Severe renal disease has been 


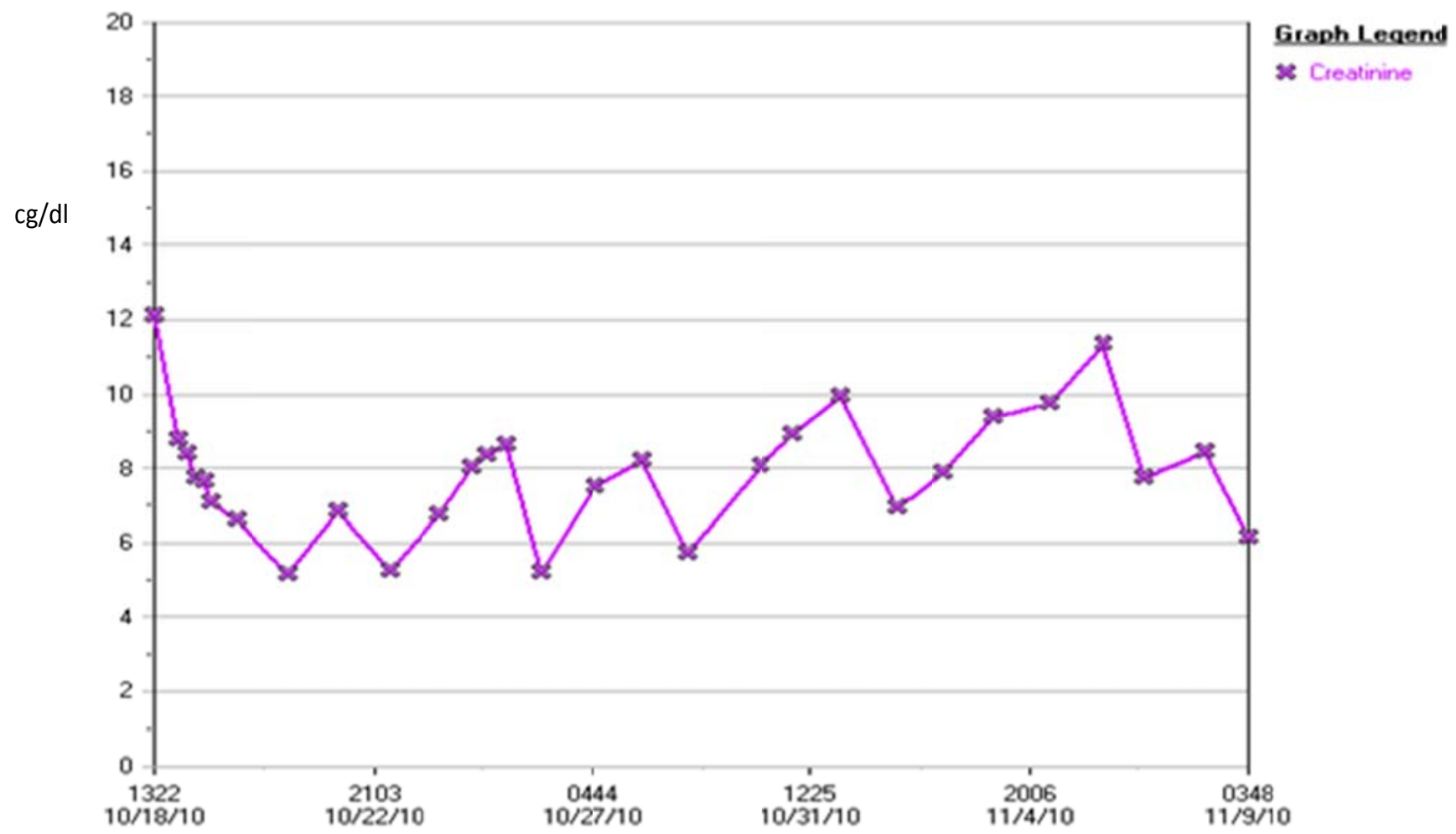

Graph 1. Trend of creatinine from admission during treatment and renal replacement until discharge when patient went home with three times a week hemodialysis.

classified by the European Vasculitis Study Group as a presenting creatinine of over $5.8 \mathrm{mg} / \mathrm{dL}$ [12]. Persistent renal impairment despite adequate treatment also leads to poor prognosis [2].

The prognosis of vasculitic disease is worse with concomitant renal impairment and pulmonary manifestations at initial presentation with the absence of upper respiratory tract involvement [2]. Those individuals that are admitted to the intensive care unit (ICU) with a suspected alveolar hemorrhage have a mortality of 25 to $50 \%$ [4]. Therefore, it is imperative to have a high index of suspicion in order to improve the outcomes. This disease is often confused with anti-GBM disease or microscopic polyangiitis (MPA). The only way to differentiate these diseases is by serology testing and confirmed with either lung or kidney biopsy. Goodpasture's syndrome is associated with high titers of anti-GBM antibody and DAH is a common presenting symptom. Goodpasture's disease is treated with plasmapheresis. MPA typically presents with capillaritis then subsequently develops Granulmatous vasculitis, but these diseases are treated very similarly with glucocorticoids and cyclophosphamide. However, in the presence of diffuse alveolar hemorrhage, immunosuppressive therapy alone can be inadequate and therefore plasmapheresis is instituted in some cases. There has been a randomized study that has shown benefit with plasmapharesis in addition to immunosuppressive therapy which includes the traditional high dose methylprednisolone with patients in severe renal diseae [12]. Due to the high mortality rate, associated with DAH and severe renal disease, our patient was plasmapheresed even before intravenous cyclophosphamide and glucocortiocoids were given and biopsy results were available. Recent evidence suggests that patients with severe ANCA-associated vasculitis, defined by the presence of DAH and/or severe renal involvement (creatinine greater than $5.7 \mathrm{mg} / \mathrm{dL}$ ), might benefit from this combination $[5,10,11]$.

\section{CONFLICT OF INTEREST}

The authors confirm that this article content has no conflicts of interest.

\section{ACKNOWLEDGEMENTS}

Dr. Karlene Hewan-Lowe from the ECU Division of Pathology for providing pathology descriptions and pictures.

\section{REFERENCES}

[1] Hoffman G, Kerr G, Leavitt R, et al. Wegener Granulomatosis: An Analysis of 158 patients. Ann Intern Med 1992; 116: 488-98.

[2] Holle JU, Laudien M, Gross WL. Clinical manifestations and treatment of wegener's granulomatosis. Rheum Dis Clin North Am 2010; 26: 507-26.

[3] Aydin Z, Gursu M, Karadag S, et al. Role of plasmapheresis performed in hemodialysis units or the treatment of antineutrophilic cytoplasmic antibody-associated systemic vasculitides. Ther Apher Dial 2010; 15(5): 493-8.

[4] Semple D, Keogh J, Forni L, Venn R. Clinical review: vasculitis on the intensive care unit - part 1: diagnosis. Crit Care 2005; 9: 92-7.

[5] Travis W, Carpenter H, Lie J. Diffuse Pulmonary Hemorrhage: An uncommon manifestation of wegner's granulomatosis. Am J Surg Pathol 1987; 11(9): 702-8.

[6] Ishiguro $\mathrm{T}$, Takayanagi $\mathrm{N}$, Yamaguchi $\mathrm{S}$, et al. Pulmonary capillaritis in wegener's granulomatosis detected via transbronchial lung biopsy. Intern Med 2012; 51: 905-9.

[7] Kim J, Park J, Wang Y, Park H, Sung S, Kim D. Diffuse Alveolar Hemorrhage in a 39-year-old Woman: unusual initial presentation of microscopic Polyangiitis. Korean J Thorac Cardiovasc Surg 2011; 44: 448-51. 
[8] Misset B, Glotz D, Escudier B, et al. Wegener's granulomatosis presenting as diffuse pulmonary hemorrhage. Intensive Care Med 1991; 17: 118-20.

[9] Haworth SJ, Savage CO, Carr D, Hughes JM, Rees AJ. Pulmonary haemorrhage complicating Wegener's granulomatosis and microscopic polyarteritis. Br Med J (Clin Res Ed) 1985; 290(6484): 1775-8.

[10] Semple D, Keogh J, Forni L, Venn R. Clinical review: vasculitis on the intensive care unit - part 2: treatment and prognosis. Crit Care 2005; 9: 193-7.
[11] Al bshabshe A, Al-Khalidy $\mathrm{H}$, Omer $\mathrm{H}$, et al. Pulmonary renal syndrome associated with Wegener's granulomatosis: a case report and review of literature. Clin Exp Nephrol 2010; 14: 80-4.

[12] Jayne DRW, Gaskin G, Rasmussen N, et al. Randomized trial of plasma exchange or high dose methylprednisone as adjunctive therapy for severe renal vasculitis. J Am Soc Nephrol 2007; 7: 2180-8.

(C) Meara et al.; Licensee Bentham Open.

This is an open access article licensed under the terms of the Creative Commons Attribution Non-Commercial License (http://creativecommons.org/licenses/by-nc/3.0/) which permits unrestricted, non-commercial use, distribution and reproduction in any medium, provided the work is properly cited. 